\title{
ENERGY-WATER-FOOD NEXUS IN THE SPANISH GREENHOUSE TOMATO PRODUCTION
}

A. Irabien* and R. Darton**

*Department of Chemical and Biomolecular Engineering. Universidad de Cantabria (Spain)

**Department of Engineering Science. University of Oxford (UK)

*E-mail: angel.irabien@unican.es

**E-mail: richard.darton@eng.ox.ac.uk

Keywords: Nexus, Energy-Water-Food, Sustainability, tomato, greenhouse production

\section{INTRODUCTION}

The need of the global population for energy, water and food is putting increasing pressure on the resources that are used to supply these basic commodities. This is not simply a result of a growing population, but is also due to urbanisation, dietary change and other consequences of economic development. This pressure is observable through negative impacts such as climate change, ocean acidification and resource scarcity. There is also collateral damage - the threat to biodiversity as more land is taken into cultivation and as chemical products escape into the environment, for example.

Water and food are necessary for all human life, and an external source of energy (additional to that provided by human muscle-power) is needed to support any society which aspires to more than a bare subsistence. The provision of the three commodities is closely linked however. Fresh water is essential to agriculture, as is the energy that is needed to produce much fertiliser, and to process, transport and distribute food products; energy is needed to desalinate or otherwise treat and then distribute water; water is used in the production and conversion of most forms of energy; where land is utilised to grow crops for processing into fuel, there is additional demand for water and potential competition with land provision for food crops. The supply chains of the three commodities are found to interact at many different points.

There are many different social, economic and environmental goals and interests in the energy, water and food system (E-W-F) conditioning the use of ecosystem services and the development of supply chains of goods and services for human well-being and environmental protection. The security of the E-W-F supply chains are of primary importance. The United Nations Development Program (UNDP 2000) has described energy security as "...continuous availability of energy in varied forms, in sufficient quantities and at reasonable prices”. Water security has been defined in the Global Water Agenda (UNU-UNWEH 2013) as "...the capacity of a population to safeguard sustainable access to adequate quantities of acceptable quality water for sustainable livelihoods, human well-being and socio-economic development, for ensuring protection against water-borne pollution and water related disasters and for preserving ecosystems in a climate of peace and political stability". The world food Summit of 1996 defined food security as existing, "when all people at all times have access to sufficient, safe nutritious food to maintain a healthy and active life" (FAO 1996; Imhoff et al. 2004).

The goals of ensuring security in energy, water and food have thus been recognized as crucial to human development, yet the links between the commodities mean that the pursuit of security in each commodity must take account of the balance of demands for all three commodities. This linkage, and the synergies and trade-offs required in meeting demands, is known as the Energy-Water-Food (E-W-F) Nexus (Hoff 2011; WEF 2011; FAO 2014). It is the objective of this paper to suggest a framework for a sustainability analysis of the E-W-F Nexus, using a simplified model of its operation. This enables the identification of sustainability impacts, clarifying the choices and trade-offs that can be made in any particular case. 
Recent studies describe the design of food production systems for sustainable value creation (Emec et al. 2015) and the challenges and opportunities derived from the carbon dioxide utilization ( Qi, Li 2015) and new techniques like Life Cycle Assessment have been recommended for the energy-water food nexus (AlAnsari et al. 2015) The result is an assessment, based on sustainability indicators, that will support better decision-making. We show how the method is applied to the case study of the tomato production in greenhouse agriculture leading to interesting results for the primary food production in semi-arid land. The application of the carbon footprint, water footprint and chemical footprint as indicators allow a quantitative assessment for the system.

\section{THE SUSTAINABILITY OF THE E-W-F SYSTEM}

\subsection{System model}

Our basic approach is that of the Process Analysis Method (PAM) proposed by Chee Tahir and Darton (2010). In this method, the system under study is described as a set of processes that produce impacts. It is the impacts that are important according to a stated definition of sustainability that are then investigated further to provide an overall assessment. The first step is the creation of a descriptive model of the system that includes all the processes that cause relevant impacts. For a large system this can be a time-consuming task, but it remains manageable because the processes do not need to be mathematically modelled, just identified and described. As is common with this type of meta-analysis, it is important to have a clear and transparent definition of system boundary.

The FAO specifically designed an assessment approach for the E-W-F Nexus (FAO, 2014) in order to “... inform nexus-related responses in terms of strategies, policy measures, planning and institutional set-up or interventions". Figure 1 summarises the FAO approach, illustrating the main drivers of change, the nature of the resource base, and how various goals and interests affect the process of managing the nexus through policy responses.

\section{Fig.1 FAO view of the E-W-F nexus (FAO 2014)}

In our simplified spatial model of the E-W-F Nexus, the three supply chains are each envisaged as operating at three scales and also have impacts at these different scales (Figure 2). The three chains (E-W-F) connect the ecosystem services that provide energy, water and land (food) resources, to the consumers. In the model are included the agents whose decisions and choices determine structure and influence the operation of the supply chains. These are institutional agents: government, regulators, etc; market agents: producers and consumers; and other stakeholders: NGO's and other, perhaps not formally organised groups, who influence institutional and market agents.

Fig.2 Multiscale approach to the E-W-F system

In the E-W-F system we identify the three main scales as: the global scale (planet), the regional scale (based on political and social agreement) and the local scale. At the different scales the institutional agents, market agents and other stakeholders are different and play different roles. The relationship among scales is based on regulations, on trade agreements and/or on market and consumers decisions, using transport and information technologies to connect the scales. At the local scale energy, water and food are produced and consumed in the same community, and communal conditions and agreements regulate supply chain. Consumers and their suppliers are part of the same community. Trade agreements are made directly between suppliers and consumers. At the regional scale suppliers and consumers are part of the same economic area, but are not part of the same social group. The global scale is multinational and characterised by large distances, different rules and regulations and supply chains subject to international agreements.

Institutional Agents, Market Agents and stakeholders define the requirements to the ecosystem services. The supply chains and their connections are organised in space and time in three different subsystems: the agri-food subsystem, the population subsystem and the industrial subsystem, with different decision agents and behaviour as shown in Figure 3.

Fig 3. Organisation of the subsystems in the E-W-F system 
The soil provides an ecosystem service to the agri-food subsystem, which has to be able in space and time to support the human food demand, supplying the chemical energy and other nutritional requirements for human well-being. The restrictions of the agri-food subsystem are based on the land, water and primary energy availability and access.

Land, water, energy and materials are also demands of the industrial and population subsystems. In general the agri-food subsystem is land and water intensive, the industrial subsystem is energy, materials and water intensive. The population subsystem, which is increasingly urban in nature, introduces an increasing demand of transport of food, water and energy to the cities which act as sinks for water, energy, materials and food, providing services to society and rejecting wastes.

In order to analyse the evolution of the system in time, local and global economic, social and natural stores of capital have to be taken into account. For sustainability these stores of value must be maintained or enhanced. This requires adaptive actions initiated and supported by institutional and market agents and other stakeholders as shown in Figure 4.

Fig.4 Sustainability in time

To establish a relationship between the land and the E-W-F system, land uses have to be taken into account at a global and local scale. The global land cover share is shown in Table 1. The preservation of biological integrity and carbon sinks have been identified as the main risks to sustainability of the land cover changes now occurring (Rockström et al 2009). As the system evolves in time Global Change signals including biodiversity losses, climate change, ocean acidification and the increasing frequency of extreme events like flooding and droughts; these have to be managed through adaptive action and mitigation to reduce local vulnerability.

Table 1. Main Land Cover Types ${ }^{\mathrm{a}}$

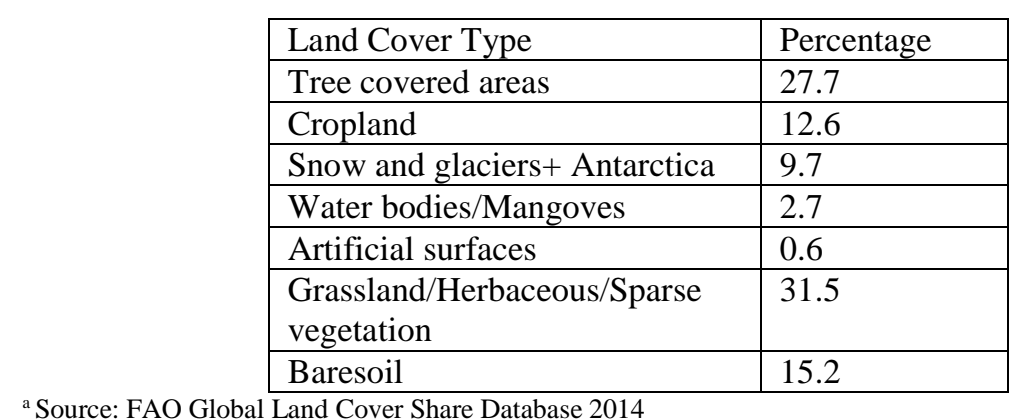

As the world's population grows, so too does the demand for food, and thus for agricultural land. UN population growth estimates are shown in Table 2, and depend on the evolution of human fertility. It is also necessary to consider changes in diet because the specific ingredients of food consumed lead to different agri-food demands and demands to the ecosystems for energy, water and land. This has been discussed for meat and plant based diets by Pimentel et al 2008. The main trade-offs are land for agri-food cropland, tree covered areas for carbon dioxide sinks and natural landscape for ecosystem services.

Approximately 16 million square kilometers of earth's surface are cultivated corresponding approximately to $2,200 \mathrm{~m}^{2} /$ person Based on a chemical energy demand of $2500 \mathrm{Kcal} /$ person day, this demand can be supplied with the cultivation of $800 \mathrm{~m}^{2} /$ person, implying that some parts of the world's cultivated surface generate more net primary production than is consumed by the human population (Imhoff et al 2004).

Table 2. World population (billion) according to different fertility projection models ${ }^{\mathrm{a}}$.

\begin{tabular}{|l|l|l|l|l|}
\hline $\begin{array}{l}\text { Fertility } \\
\text { /year }\end{array}$ & Low & Medium & High & Constant \\
\hline 2015 & 7256 & 7324 & 7392 & 7353 \\
\hline 2025 & 7768 & 8083 & 8398 & 8373 \\
\hline 2050 & 8341 & 9550 & 10868 & 11089 \\
\hline 2100 & 6750 & 10853 & 16641 & 28646 \\
\hline
\end{tabular}

a Source: United Nations, Department of Economic and Social Affairs Population Division Population Estimates and Projections Section: The 2012 Revision 
In the population subsystem, the movement of people from rural to urban environments is an important driver of change, because of the consequent change in demands on the agri-food subsystem (generally located in a rural environment) and the industrial subsystem. In turn this alters specific fluxes of materials and energy among the three subsystems. In general the agri-food subsystem supplies the primary ingredients of food based on soil exploitation, the industrial subsystem supplies materials, energy and water and the cities receive the services of chemical energy (food), physical energy and clean water generating municipal wastewater and solid wastes.

To develop a quantitative analysis, the supply of the human chemical energy demand per person (KcalF/person day) requires primary ingredients according to the individual diet (social/personal decision), which plays an important role in the interactions between land, energy and water demands in the supply chains. Two main socially undesirable results are evident: undernutrition and obesity due to extreme inequalities in the system and unhealthy producer/consumer behaviour respectively.

The agri-food subsystem applies different cultivation methods. Depending on the soil, water and energy and the knowledge, technology and human resources available, the options are generally: rainfed, irrigation and greenhouse production. The choice of agri-food subsystem processes influences the soil and water degradation depending on the local vulnerability. Soil degradation is considered a significant human global risk (Amundson et al 2015) connected to population growth, food demand and soil overexploitation. Agrifood productivity has increased using fertilizers and pesticides, which connect the agri-food subsystem to the industrial subsystem.

The agri-food system is a major consumer of fresh water, but the demand from the industrial and population sub-systems must also be considered. There is a growing need to tackle water quality degradation through accumulation of fertilizers in biochemical cycles (Phosphorous, Nitrogen) and the introduction of novel entities in the aquatic media where pesticides and fungicides are emerging pollutants (Rockström et al. 2009). But waste waters from the industrial sub-system, and from the population sub-system where contaminants range from untreated sewage to recalcitrant pharmaceutical residues, also pose a challenge.

\subsection{Defining sustainability}

A convenient start to this sustainability analysis is to work from the Brundtland definition of sustainability, deriving specific requirements in order to meet the overall objectives of the definition. Brundtland's definition requires sustainable development "...to meet the needs of the present without compromising the ability of future generations to meet their own needs" (Bruntland 1987). For the E-W-F system to be sustainable it must be able to provide Availability, Accessibility and Utilisation (AAU) of energy, water and food for human well-being, whilst at the same time safeguarding the extent and diversity of the planet's ecosystems in space and time. Broadly this requires sustainable and efficient resource use and fairness in distribution of benefits and disbenefits in the economic and social balance.

Achieving sustainability of the E-W-F system in practice requires the design and adaptation in time of the energy, water and food (chemical energy and nutritional value) supply chains for human demands taking into account the limitation of the ecosystem services in space and time. The key criteria can be described as the Availability, Accessibility and Utilization and the enabling processes to be managed can be identified as the Supply Chains as shown in Figure 4. The objective is to design a sustainable supply/demand balance considering the evolution of the economic, social and environmental stores of capital. The system must facilitate adaptive actions based on decisions of the Institutional Agents, Market Agents and other stakeholders leading to greater sustainability.

According to the different approaches to the problem (Hoff 2011; WEF 2011; FAO 2014) population growth, urbanisation and global change (biodiversity, land use change and climate change), are the main drivers to be considered in time for the system. Due to globalisation a constant increase of the transport and trade of goods and services among the agri-food, industrial and population subsystems has to be expected connecting local to global scenarios. Further, economic and social inequity and inequalities also present challenges to a sustainable E-W-F system, which needs to be able to adopt necessary mitigation and adaptation strategies. Land use and land use change are connected to global changes mainly due to the relationships between land cover, biodiversity and greenhouse gases sinks. Land cover change is related to intensive agri-food production and urbanization, which may threaten ecosystems in their genetic and 
functional diversity, leading to biodiversity extinction (Rockström et al. 2009) if adaptation policies are not implemented. Further, land cover change may exacerbate climate change if, as is often the case it involves the destruction of carbon dioxide sinks. It means that the first quantitative reference of the analysis has to be the area of land used by the three different subsystems. To connect the subsystems, with their widely differing population densities, transport is a growing human activity, which demands mainly energy from the ecosystem services.

In the E-W-F system, the three subsystems connect the supply of natural resources from the ecosystem services based on the energy/materials, water and soil stores to the human demand of physical energy, water and chemical energy. Taking the land (m2) as reference for the supply of Food, Water and Energy, three variables describing the Energy Resource-Water Resource-Food Resource (ER-WR-FR) fluxes referred to the land area of the ecosystem can be defined to relate the supply with the human demand: FR (KcalF/m²time) being KcalF the human chemical energy supplied by the food, WR Water Supply $\left(\mathrm{m}^{3} / \mathrm{time}^{2}\right)$ and $\mathrm{ER}\left(\mathrm{KJ} / \mathrm{m}^{2}\right.$ time$)$.

The multiscale approach to the planet now requires integration of the different local scale ecosystem services with different qualities of soil and land use generating flows of chemical energy as food, physical energy and water from the local scale to the global scale. This can be transformed into material and energy flows in the specific supply areas, adding transport as shown in Figure 5. In this approach the land area of the ecosystem services supply (A) is in general different to the land area occupied by the population. The relationship to manage the population growth is a supply-demand balance depending on the area supplying ecosystem services and the number of persons demanding Energy, Water and Food from the area.

Fig.5 Relationship between ecosystem services and human well-being

The relationship between the fluxes of the ecosystem services and the quantitative and qualitative variables are shown in Table 3. The flows of ER-WR-FR ecosystem services for human well-being are related to the sustainable management of the materials/energy, water and soil stores. They include the appropriate maintenance of the ecosystem services to counter the degradation of natural resources and their consumption. Transport is included as shown in Figure 6.

Table 3. Main variables in the E-W-F system: supply and demand

\begin{tabular}{|l|l|l|l|}
\hline Supply Chains & Ecosystem services supply & $\begin{array}{l}\text { Human } \\
\text { demand }\end{array}$ & Qualitative variable \\
\hline Energy & $\mathrm{KJ} / \mathrm{m}^{2}$ year $(\mathrm{ER})$ & $\mathrm{KWh} /$ person year $(\mathrm{E})$ & Renewable energy \\
\hline Water & $\mathrm{m}^{3} / \mathrm{m}^{2}$ year $(\mathrm{WR})$ & $\mathrm{m}^{3} /$ person year $(\mathrm{W})$ & Renewable Water \\
\hline Food & $\mathrm{KgF} / \mathrm{m}^{2}$ time $(\mathrm{FR})$ & $\mathrm{KcalF} /$ person year $(\mathrm{F})$ & Soil quality/Food Quality \\
\hline
\end{tabular}

Fig.6 Interactions of the supply chains

\section{E-W-F SUPPLY CHAIN FRAMEWORK}

Assuming a supply chain view of ecosystem service provision to the final consumers in the Energy-WaterFood system: materials (including primary energy), water and land (soil) are the ecosystem services providing availability, access and utilization. Because energy, water and food follow different transformations in the individual supply chains, the material and energy balances depend also on the interactions among the three chains. Thus a complex network of supply chains connects with the ecosystem services where sources and uses are connected (Gilson 2014).

Table 4 Energy and binary interactions (IEA 2015; IRENA 2015, FAO 2014)

\begin{tabular}{|l|l|l|l|}
\hline Supply Chains & ER & WR & FR \\
\hline E & E/ER & E/WR & E/FR \\
\hline W & W/ER & W/WR & W/FR \\
\hline F & F/ER & F/WR & F/FR \\
\hline \multicolumn{5}{|l|}{} \\
\hline Boundaries & ER (Mtoe) & E (Mtoe) & E/ER \\
\hline
\end{tabular}




\begin{tabular}{|l|l|l|l|}
\hline OECD & 7008 & 3582 & 0,51 \\
\hline World & 18607 & 8980 & 0,48 \\
\hline China & 3067 & 1711 & 0,56 \\
\hline \multicolumn{3}{|l|}{} \\
\hline Binary Parameter & $\begin{array}{l}\text { Groundwater/ } \\
\text { River-Lake }\end{array}$ & $\begin{array}{l}\text { Waste Water } \\
\text { Treatment/Reuse }\end{array}$ & Seawater \\
\hline E/WR (KWh/m3) & $0.1-0.5$ & $1-2.5$ & $2.5-8.5$ \\
\hline
\end{tabular}

According to Table 4, the efficiency of the relationship between ecosystem services and human demand depends on nine factors connecting the availability, accessibility and utilization of natural resources to human demands. Three single resource factors: E/ER, W/WR and F/FR describe the way in which the demand for energy, water and food (E-W-F) are supplied from the ecosystem services (ER-WR-FR).

An assessment of the E-W-F system depends not only on the quantity of natural resources involved in the specific supply chains, which is a restriction of the ecosystems in time and space, but also on the specific interactions among the supply chains, thus on the supply chain design and management. The supply of the human demands has an influence in the stores of materials (energy), water and land leading to a quality degradation due to its use and to the economic and social development in the human organisation subsystems, which has been simplified previously to agri-food, industrial and population subsystems.

As an example, the ratio E/ER corresponds to the relationship between the final form of the human demand of energy for industry, transport and other uses (E) and the ecosystem services supply of energy (ER). The International Energy Agency presented data of the world primary energy demand and the final energy use and Table 4 shows the numbers for the year 2012 with different boundaries. A qualitative analysis of these data shows that the global efficiency is near $50 \%$ of the primary resources, according to IEA data (IEA 2015). Energy resource is greater than energy delivered (because of losses in conversion, distribution, etc.) and a quality assessment shows a share of $13.5 \%$ of renewables at a global scale in 2012 , largely due to the contribution of biomass. From a global point of view approximately $1 / 3$ of the final consumption of energy is related to the industrial subsystem, 1/3 to transportation and the rest to various other uses. The population and agri-food subsystems play minor direct roles in the global energy demand, but due to globalisation the transport of persons, goods and services plays a growing role in the energy demand from the ecosystem services.

The agri-food subsystem accounts for approximately $70 \%$ of the total world fresh water demand. The population and industrial subsystems demand different quantities and qualities related to the local availability of the ecosystem service. In contrast to the conventional view, it has been noted that evapotranspiration from non-irrigated cropland also is a water resource that is beneficial to society. To differentiate this resource from conventional resources, evapotranspiration flow is named green water, and conventional withdrawal from rivers and groundwater is named blue water. About $3800 \mathrm{~km}^{3} /$ year of Renewable Fresh Water Resources (RFWR - blue water) is currently withdrawn for human use, and that accounts for less than $10 \%$ of the maximum available global RFWR. The problem is the high variability of water resource availability in time and space. Artificial reservoirs, lakes and ponds are required to balance supply and demand fluctuation and most of the major rivers are regulated in some way. Total capacity of the artificial storage is estimated to be $7200 \mathrm{~km}^{3}$, about twice the annual water withdrawal (Oki and Kanae 2006). The supply refers to the freshwater demand of the ecosystems but different natural water qualities can be managed in the water supply chain requiring supplementary energy for the upgrade as indicated in Table 4 by the range of E/WR binary interaction parameter.

Food supplies the chemical energy contained in the primary ingredients of food $(\mathrm{F})$, which demand depends on the composition of the diet. The primary ingredients of food are related to the ecosystems services by the land use (F/FR), which describes the relationship between the primary ingredients of food (KcalF or Kg of the specific food) and the productivity of the land $\left(\mathrm{m}^{2}\right)$ and agri-food cultivation system during a period of time. Table 1 shows the small fraction of surface freshwater in the land cover, W/LR $=2,6 \%$ and the different properties of the specific land cover, with different functionalities and qualities. F/WR is the relationship between food supply and specific water demand which is connected to the agri-food cultivation processes and food product manufacture. The cultivation process shows mainly three methods: rainfed, irrigation and greenhouse agriculture, and many different possibilities of food processing. 
Water Resources, WR, can be renewable like rain or rivers and from non-renewable or slowly-renewable like groundwater and from upgrading of brackish or seawater. The E-W-F supply chains consume nonrenewable resources and bring about a quality degradation due to the environmental burdens associated with the transformations (Gleick 1996).

\section{CASE STUDY: TOMATO PRODUCTION IN GREENHOUSE AGRICULTURE}

In order to demonstrate this integrated supply chain approach to the Nexus, we applied the Process Analysis Method (Darton 2015) to a case study. The tomato Energy-Water-Food system in the Almeria province of Spain has been taken as example because it has been studied previously from different points of view (Galdeano-Gomez et al 2013; Chico et al 2010; Chapagain and Orr 2009; Torrellas et al 2012). It shows a process of change in the E-W-F system based on the intensification of the agri-food system in a semi-arid land to supply tomatoes for a growing European market. The greenhouse production system is based on the use of artificial soil and controlled water and energy supplies. Almeria (province of Spain) has now an estimated 40,000 hectares of greenhouses in the "Campo de Dalias", the largest concentration in the world, which has changed strongly the landscape in the period 1974-2004 (Geographyfieldwork 2015).

Over 2.7 million tonnes of produce (aprox 1.2 million ton tomato) are grown on the plain each year. From the economic point of view the place has a comparative advantage in the european market with production costs less than half of other european countries. Due to the warm weather energy consumption is lower and greenhouse construction and workforce is available based on small exploitations (aproximately 1-1.4 hectares in size) managed by their owners (Galdeano-Gomez et al 2013). The economic activity around greenhouses accounted for over 1.2 billion $€$ in 2010 , and the employment is seasonal affecting many temporary workers in the peaks. The productivity from 1975 to 2010 increased steadily from 100 to 200 ton/hectare, maintaining the economic sustainability (Galdeano-Gomez et al 2013). The family companies generally retain low labour costs and have strong motivation to work, but producers use temporary labour and the amount of temporary work appears to be a social risk in the area.

The crops are grown continuously from October to July with production peaks in December-January when the tomato is in season and then again in May-June when another crop, melons, are in season; tomatoes and sweet pepper represent the greatest crop area followed by melons. Approximately $90 \%$ of the greenhouses use an artificial soil called "Enarenado" in order to overcome the extremely poor indigenous soils in the region. The synthetic soil is a mix of clay, manure and sand that sits on top of the original soil base. In the remaining greenhouses, plants will never touch soil, they grow using a hydroponics system where chemical fertilizers are drip-fed to each plant from large computer-controlled vats. Associated with the use of artificial soil and greenhouses, fertilizers and pesticides have to be supplied to reach the high productivity.

The main variables of the tomato production are shown in Table 5 where the land, water, energy and chemicals are evaluated in terms of productivity per square meter, water footprint, carbon footprint and chemicals footprint respectively.

Table 5. Relationship between land, water footprint, chemicals footprint and carbon footprint of the tomato production (Chico et al 2010; Chapagain and Orr 2009; Torrellas et al 2012)

\begin{tabular}{|c|c|c|c|c|c|c|c|}
\hline \multicolumn{2}{|c|}{ Production System } & $\begin{array}{l}\text { Green } \\
\text { Water } \\
\text { Footprint } \\
\text { (m3/ton) }\end{array}$ & $\begin{array}{l}\text { Blue } \\
\text { Water } \\
\text { Footprint } \\
\text { (m3/ton) }\end{array}$ & $\begin{array}{l}\text { Grey } \\
\text { Water } \\
\text { Footprint } \\
\text { (m3/ton) }\end{array}$ & $\begin{array}{l}\text { Productivity } \\
(\mathrm{Kg} / \mathrm{m} 2 \\
\text { year) }\end{array}$ & $\begin{array}{l}\text { Chemical } \\
\text { Energy } \\
\text { (Kcal/m2 } \\
\text { year) }\end{array}$ & $\begin{array}{l}\text { Water } \\
\text { (m3/ton) }\end{array}$ \\
\hline \multicolumn{2}{|l|}{ Rainfed } & 158 & 0 & 808 & $1-4$ & $0.18-7.2$ & 966 \\
\hline \multicolumn{2}{|l|}{ Irrigated } & 7 & 110 & 149 & $4-8$ & $7.2-14.6$ & 266 \\
\hline \multicolumn{2}{|l|}{ Greenhouse } & 0 & 66 & 121 & $10-12$ & $54-72$ & 179 \\
\hline \multicolumn{2}{|l|}{ Greenhouse } & $\mathrm{N}$ & $\mathrm{P}$ & $\mathrm{K} 2 \mathrm{O}$ & Insecticides & Fungicides & \\
\hline \multicolumn{2}{|l|}{$\mathrm{Kg} / \mathrm{ha}$} & 800 & 500 & 1500 & 3,8 & 28,5 & \\
\hline $\begin{array}{l}\text { Carbon } \\
\text { Footprint }\end{array}$ & Struct & Climat. & $\begin{array}{l}\text { Auxiliary } \\
\text { equipment }\end{array}$ & Fertilizers & Pesticides & Waste & $\begin{array}{l}\text { TOTAL } \\
\text { Greenhouse }\end{array}$ \\
\hline
\end{tabular}




\begin{tabular}{|l|l|l|l|l|l|l|l|}
\hline $\begin{array}{l}\mathrm{kgCO} / \mathrm{ton} \\
\text { tomato }\end{array}$ & 88 & 15 & 77 & 82 & 2 & 3.1 & 250 \\
\hline
\end{tabular}

The water footprint shows volumes but also the type of water use: evaporation of rainwater (green), surface water or groundwater (blue) or pollution of water (grey). Table 5 shows the estimated water footprint of the different production methods of tomato, considering green, blue and grey water. Greenhouse production of tomato has a requirement of $800-1000 \mathrm{~m}^{3} / \mathrm{m}^{2}$ water per year in a region that receives just $200 \mathrm{~m}^{3} / \mathrm{m}^{2}$ of annual rainfall. Water efficiency has improved dramatically, especially with the use of drip irrigation, but the availability of renewable water is not sufficient, and use of groundwater and/or brackish water or seawater desalination is now necessary. This increases the energy demand.

The local environmental sustainability keypoint is the trade-off between the vulnerability and sensitivity of the local aquatic ecosystems and the energy and economic demands of desalination. As a consequence, in the province of Almeria most of the water bodies are at risk of no compliance with the European Water Framework Directive (IMA 2011) and water stress due to the overexploitation of groundwater is common. A new seawater desalination plant opened in 2009 supplying $60,000 \mathrm{~m} 3 /$ day of freshwater to the region is now in use.

The transfer of fertilizers and pesticides to the water bodies has to be controlled avoiding the impact of nitrogen and phosphorous accumulation and the presence of novel entities in the water bodies (pesticides).

The change in the production method of tomato includes new physical structures (greenhouses) and technology (pumps, temperature control, etc) demanding energy. A detailed Life Cycle Assessment of the greenhouse production method in Almeria has been recently published, and the main results are included in Table 5, as the contribution to the carbon footprint (Torrellas et al 2012). The carbon footprint of the tomato production has been widely studied, and depends on the production process and supply chain (especially whether or not the transport of product to a distant market is included) leading to a range between 70 to $700 \mathrm{kgCO} 2 /$ ton tomato (Page et al 2012).

The supplementary energy required for desalination of seawater and/or for the use of brackish water is in the range of 0,4-4 kWh/m3 from brackish water (Fernandez-Gonzalez et als 2015) and 2,5-8,5KWh/m3 for seawater (IRENA 2015)

\section{DISCUSSION}

According to the literature in a global analysis of the E-W-F system ten planetary boundaries have been suggested corresponding to possible planetary risks: (a-b) Biosphere integrity, based on genetic and functional diversity, (c-d) Biochemical flows of nitrogen and phosphorous, (e-f) Land system change and climate change, (g-h) stratospheric ozone depletion and freshwater use and (i-j) novel entities and atmospheric aerosol loading (Steffen 2015). In the E-W-F system the biosphere integrity has to be mainly controlled through managing land use change and soil degradation caused by agriculture.

The biochemical flows of nitrogen and phosphorous are related to the fertilizers produced in the industrial subsystem and used in the agro-food system leading local eutrophication processes, which have to be controlled in the nitrogen and phosphorous cycle. Land system change and climate change require an equilibrium between the greenhouse gases emissions mainly from the energy sector and the natural sinks leading to ocean water acidification and climate change.

Stratospheric ozone depletion is now under control, but freshwater use is increasing and attention has to be paid to the novel entities involved in the E-W-F system like pesticides in the agri-food system. On the other side the continuous soil degradation due to the application of intensive agro-food production methods has been suggested in a recent paper as an important risk for the next future (Amundson 2015))

From a socio-economic view, it has to be remarked that unequal distribution of food per person in the world as a global social concern, clearly signalled by both undernutrition and obesity. access to clean water and sanitation and the economic affordability of energy for human wellbeing are two important objectives for the society, connecting social risks with economic risks. 
Table 6 shows a general overview of the main risks, which can be identified in the supply chain framework of the E-W-F system.

Table 6. Risks in the Energy-Water-Food System from a supply chain view.

\begin{tabular}{|c|c|c|c|}
\hline RISKS & $\begin{array}{l}\text { NATURAL } \\
\text { CAPITAL }\end{array}$ & $\begin{array}{l}\text { ECONOMIC } \\
\text { CAPITAL }\end{array}$ & $\begin{array}{l}\text { SOCIAL } \\
\text { CAPITAL }\end{array}$ \\
\hline AVAILABILITY & $\begin{array}{l}\text { Supply of ecosystem } \\
\text { services. } \quad \text { Variability } \\
\text { and degradation. }\end{array}$ & $\begin{array}{lr}\text { Unsustainable resources } \\
\text { exploitation. } & \text { Local } \\
\text { depletion of resources }\end{array}$ & Governance and Conflicts \\
\hline ACCESS & $\begin{array}{l}\text { Climate Change. } \\
\text { Extreme Events. Local } \\
\text { Depletion }\end{array}$ & $\begin{array}{lcr}\text { Planning, design and } \\
\text { economic support } \\
\text { Infrastructures }\end{array}$ & $\begin{array}{l}\text { Energy poverty, clean water } \\
\text { and sanitation and } \\
\text { undernutrition and obesity }\end{array}$ \\
\hline UTILISATION & $\begin{array}{l}\text { Local Ecosystems } \\
\text { irreversible damaged }\end{array}$ & $\begin{array}{l}\text { Supply Chain Added } \\
\text { Value. Global Trade. }\end{array}$ & $\begin{array}{l}\text { Global agreements. Equity } \\
\text { and efficiency }\end{array}$ \\
\hline
\end{tabular}

The supply chain framework in the E-W-F system depends on the local stores of materials/energy, water and land and the design of the supply chains. Their evolution has to be planned to support the demands of the population and subsystems in both quantity and quality. At a local/regional scale, key roles are played by infrastructures, trade and transport in the supply chains, from the economic and social point of view. The planning and organisation of the population, agri-food and industrial subsystems is the main way to interact with the natural capital and ecosystem services through the E-W-F supply chains. Energy/materials use and degradation, water use and quality degradation and land use and soil degradation are the main indicators to connect the natural capital and the ecosystem services to the human demands to design a sustainable evolution based on adaptive economic and social actions in time and space. Water Footprint, Carbon Footprint and Chemicals Footprint are quantitative estimations to compare different alternatives in the E-W-F supply chains to assess the scenarios.

\section{CONCLUSIONS}

A Life Cycle Sustainability Assessment (LCSA) of the E-W-F Almeria's tomato supply chains taking into account the local, regional and global scale allows us to identify risks to be considered by the institutional agents, market agents and stakeholders involved.

The socio-economic assessment of the tomato case study shows a sustainable development based on the access to the European market and the quality control of the production process, where the water availability, access and utilisation is the main risk. In the process of change (1974-2004) the greenhouse production has shown an important landscape degradation and a high freshwater demand (Water Footprint) which cannot be met from renewable sources due to the low rainfall and river flows in the region.

The social changes due to the production process referred to the workforce, economic competitiveness in the European markets, and the availability of water and energy are the main risks to be addressed in the tomato sustainability case study, suggesting that water footprint, carbon footprint and chemicals footprint are simple but effective metrics to monitor the system.

\section{REFERENCES}

Amundson, R et al (2015) Soil and human security in the 21stcentury Science vol 348 (6235) 1261071 doi: $10.1126 /$ science. 1261071

Bruntland, G. (ed.), (1987), "Our common future: The World Commission on Environment and Development", Oxford, Oxford University Press. 
Chapagain, A K Orr, S (2009) An improved water footprint methodology linking global consumption to local water resources. A case of Spanish tomatoes Journal of Environmental Management 90: 1219-1228

Chee Tahir, A. and Darton, R. C., (2010) The Process Analysis Method of selecting indicators to quantify the sustainability performance of a business operation. J. Clean Prod, 18 (16-17), pp. $1598-1607$

Chico, D Salmoral, G Llamas, M Garrido, RA and Aldaya, MM (2010) "The Water Footprint and Virtual Water Exports Of Spanish Tomatoes" Papeles de Agua Virtual. Observatorio del Agua Edita: Fundación Marcelino Botín ISBN: 978-84-966-55-80-5 (Número 8), Madrid.

Darton, R. (2015). Setting a policy for Sustainability: the importance of measurement in, "Assessing and Measuring Environmental Impact and Sustainability". Chapter 14 Ed. Jiri Klemes. Butterworth-Heinemann

Emec, S. Bilge, P. Seliger, G. (2015) Design of production systems with hybrid energy and water generation for sustainable value creation Clean Techn Environ Policy 17:1807-1829

FAO (1996) Declaration on world food security. World Food Summit, Rome: Food and Agriculture Organization of the United Nations.

FAO (2014) Walking the Nexus talk: Assessing the Water-Energy-Food Nexus, Rome: Food and Agriculture Organization of the United Nations, E-ISBN 978-92-5-108488-5.

Fernandez-Gonzalez, C Dominguez-Ramos, A Ibañez, R Irabien, A (2015) Sustainability assessment of electrodialysis powered by photovoltaic solar energy for freshwater production Renewable and Sustainable Energy Reviews 47: 604-615

Galdeano-Gómez, E. Aznar-Sánchez, JA. Pérez-Mesa, JC. (2013) International Journal of Agricultural Sustainability 11, 125-143.

Geographyfieldwork (2015) http://geographyfieldwork.com/AlmeriaClimateChange.htm. Barcelona Fieldstudies Centre webpage. Accesed June 2015

Gilson, J (2014) Water-Energy nexus:matching sources and uses Clean Techn Environ Policiy 16:1471-1479

Hoff, H. (2011) Understanding the Nexus. Background Paper for the Bonn2011 Conference: The Water, Energy and Food Security Nexus. Stockholm Environment Institute.

IEA (2015) Internet page. http://www.iea.org/Sankey/index.html . Accesed June 2015.

IMA (2011) Annual Report on the Environment in Andalusia. ISSN 2174-9108. Junta de Andalucia.

Imhoff ML, et al. (2004) Global Patterns in Human Consumption of Net Primary Production Nature, 429, 6994: 870-873

IRENA(2015) "Renewable Energy, in the Water,Energy and Food Nexus" http://www.irena.org/DocumentDownloads/Publications/IRENA_Water_Energy_Food_Nexus _2015.pdf

Oki, T Kanae, S (2006) Global Hydrological Cycles and World Water Resources Science 313 (5790) 1068-1072 DOI: 10.1126/science.1128845

Page, G. Ridoutt, B. Bellotti, B. (2012) "Carbon and water footprint tradeoffs in fresh tomato production" Journal of Cleaner Production 32:219-226

Pimentel D, Pimentel MH. (2008). Food, energy and society, 3rd edn. Boca Raton: CRC Press. 
Qi, Li Water-CCUS nexus: challenges and opportunities of China's coal chemical industry Clean Techn Environ Policy (2015) DOI 10.1007/s/0098-015-1049-z

Rockström, J. et al. (2009) Planetary boundaries: Exploring the safe operating space for humanity. Ecol. Soc. 14, 32

Steffen, W. et al. (2015) Planetary boundaries: Guiding human development on a changing planet Science 347, 6223

Torrellas, M et al (2012) LCA of a tomato crop in a multi-tunnel greenhouse in Almeria" LCA For Agiculture Int J Life Cycle Assess 17:863-875

UNDP (2000) World Energy Assessment - Energy and the Challenge of Sustainability. United Nations Development Program.

UNU-UNWEH (2013) Water Security and the Global Water Agenda. United Nations University

WEF (2011) Global risks 2011. 6th Edition. World Economic Forum, Cologne/Geneva. 
Fig.1

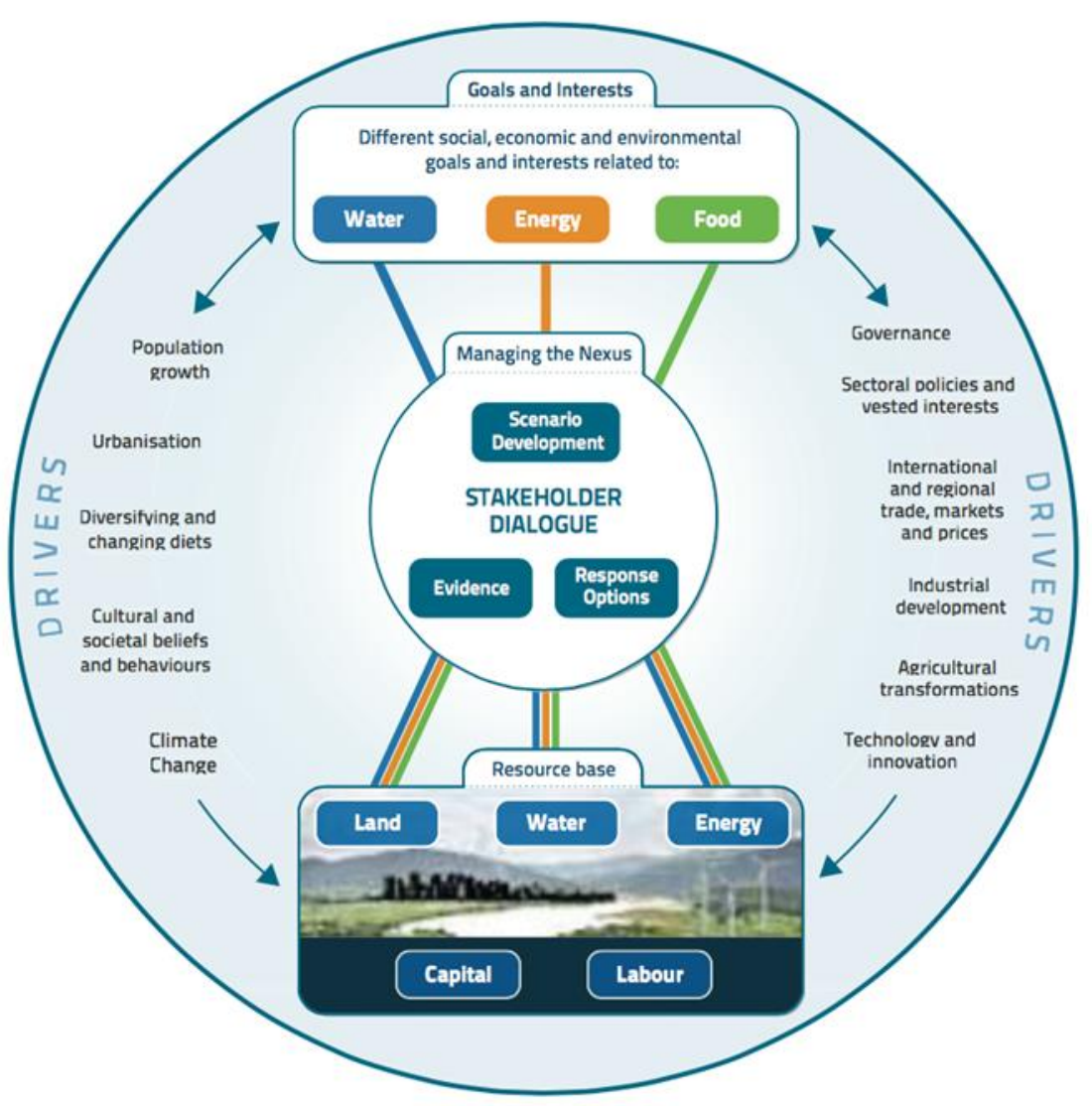




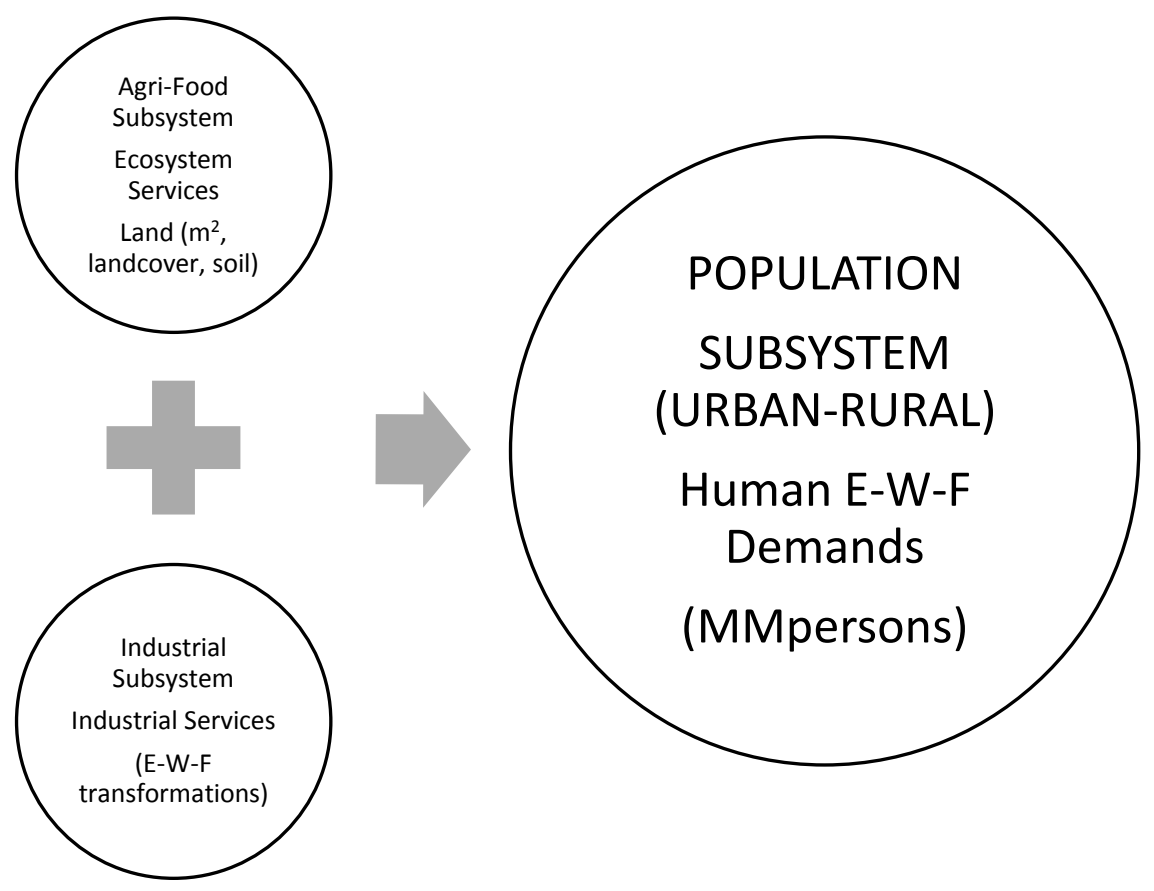

Fig.3 


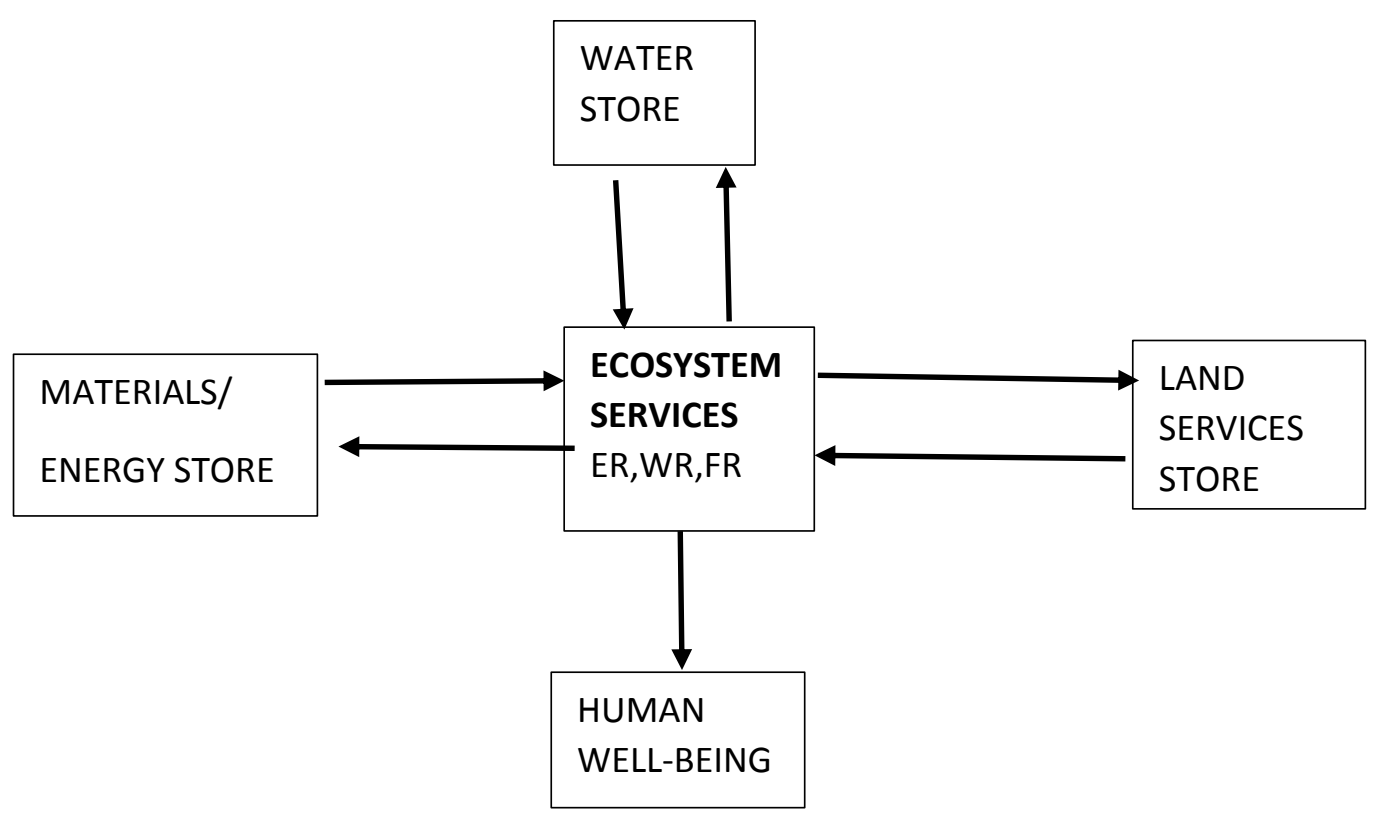

Fig. 5 
Fig. 6

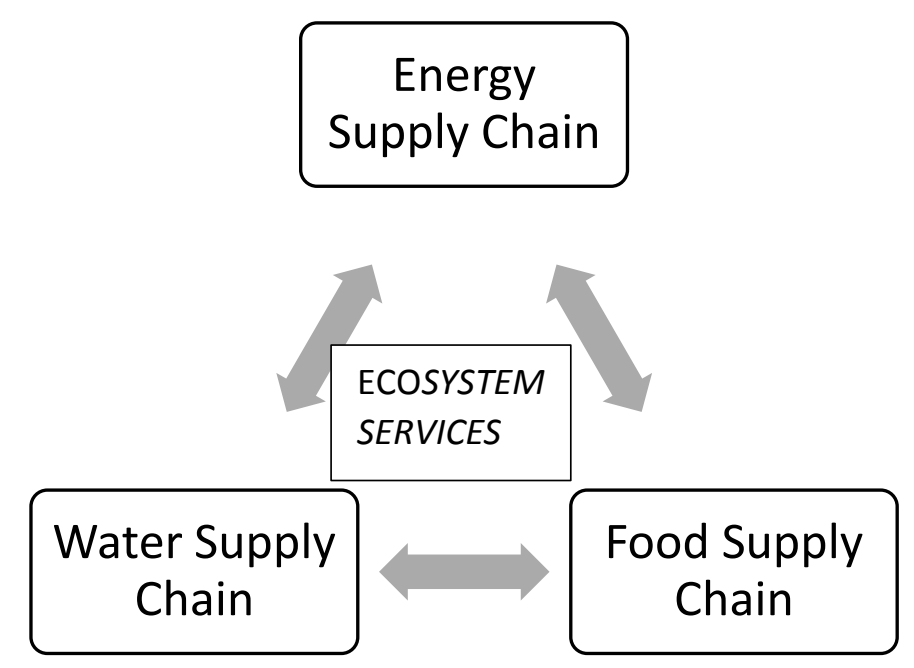

Water Supply
Chain $\Rightarrow \begin{gathered}\text { Food Supply } \\ \text { Chain }\end{gathered}$




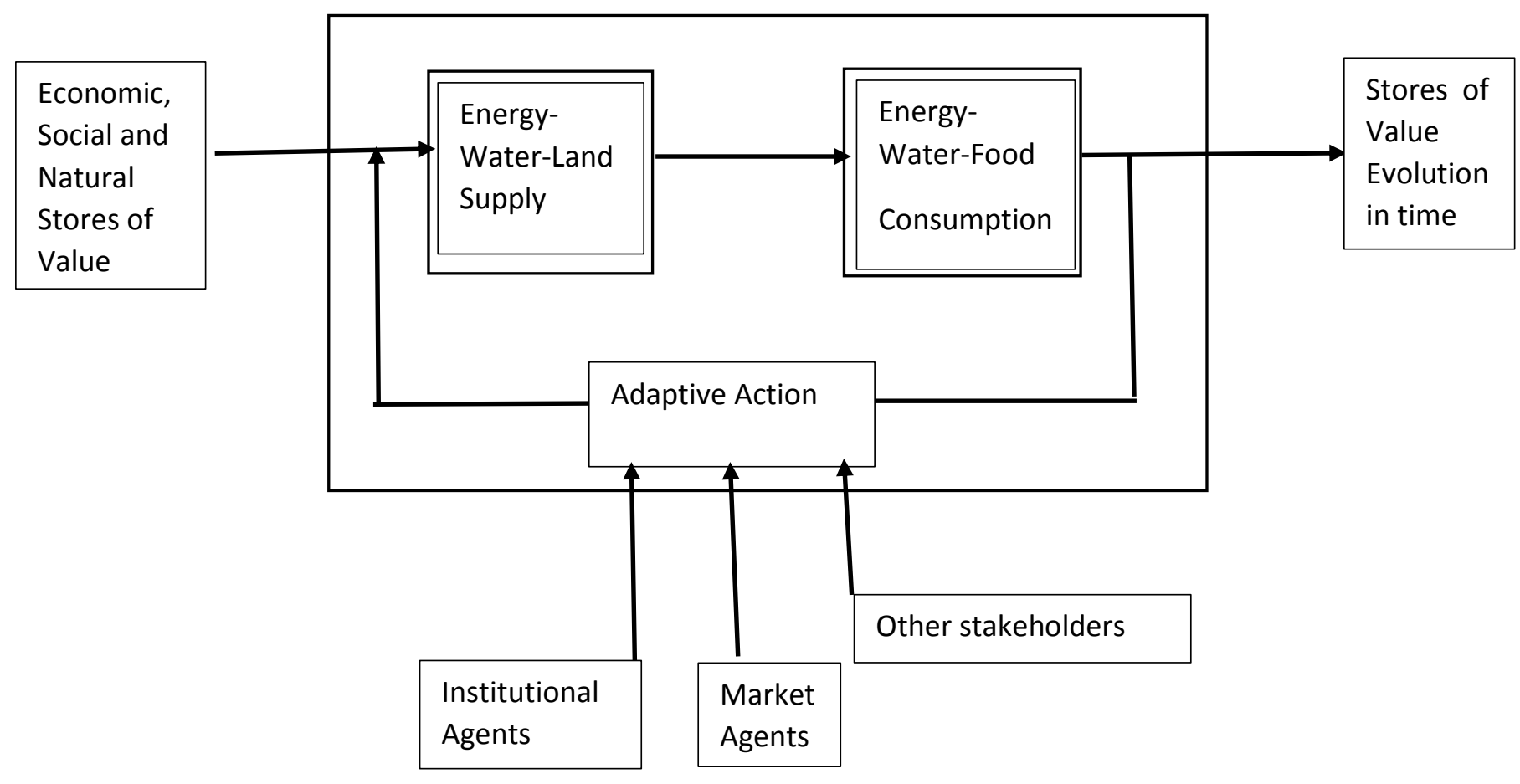

Fig. 4 
Table 1. Main Land Cover Types ${ }^{\mathrm{a}}$

\begin{tabular}{|l|l|}
\hline Land Cover Type & Percentage \\
\hline Tree covered areas & 27.7 \\
\hline Cropland & 12.6 \\
\hline Snow and glaciers+ Antarctica & 9.7 \\
\hline Water bodies/Mangoves & 2.7 \\
\hline Artificial surfaces & 0.6 \\
\hline $\begin{array}{l}\text { Grassland/Herbaceous/Sparse } \\
\text { vegetation }\end{array}$ & 31.5 \\
\hline Baresoil & 15.2 \\
\hline
\end{tabular}

${ }^{\text {a }}$ Source: FAO Global Land Cover Share Database 2014 
Table 2. World population according to different fertility projection models ${ }^{\mathrm{a}}$.

\begin{tabular}{|l|l|l|l|l|}
\hline $\begin{array}{l}\text { Year } \\
\text { /Billions }\end{array}$ & Low & Medium & High & Constant \\
\hline 2015 & 7256 & 7324 & 7392 & 7353 \\
\hline 2025 & 7768 & 8083 & 8398 & 8373 \\
\hline 2050 & 8341 & 9550 & 10868 & 11089 \\
\hline 2100 & 6750 & 10853 & 16641 & 28646 \\
\hline
\end{tabular}

a Source: United Nations, Department of Economic and Social Affairs Population Division Population Estimates and Projections Section: The 2012 Revision 
Table 3. Main variables in the E-W-F system: supply and demand

\begin{tabular}{|l|l|l|l|}
\hline Supply Chains & Ecosystem services supply & $\begin{array}{l}\text { Human } \\
\text { demand }\end{array}$ & Qualitative variable \\
\hline Energy & $\mathrm{KJ} / \mathrm{m}^{2}$ year $(\mathrm{ER})$ & $\mathrm{KWh} /$ person year $(\mathrm{E})$ & Renewable energy \\
\hline Water & $\mathrm{m}^{3} / \mathrm{m}^{2}$ year $(\mathrm{WR})$ & $\mathrm{m}^{3} /$ person year $(\mathrm{W})$ & Renewable Water \\
\hline Food & $\mathrm{KgF} / \mathrm{m}^{2}$ time $(\mathrm{FR})$ & $\mathrm{KcalF} /$ person year $(\mathrm{F})$ & Soil quality/Food Quality \\
\hline
\end{tabular}


Table 4 Energy and binary interactions (IEA 2015; IRENA 2015, FAO 2014)

\begin{tabular}{|l|l|l|l|}
\hline Supply Chains & ER & WR & FR \\
\hline E & E/ER & E/WR & E/FR \\
\hline W & W/ER & W/WR & W/FR \\
\hline F & F/ER & F/WR & F/FR \\
\hline \multicolumn{5}{|l|}{} \\
\hline Boundaries & ER (Mtoe) & E (Mtoe) & E/ER \\
\hline OECD & 7008 & 3582 & 0,51 \\
\hline World & 18607 & 8980 & 0,48 \\
\hline China & 3067 & 1711 & 0,56 \\
\hline \multicolumn{5}{|l}{} \\
\hline Binary Parameter & $\begin{array}{l}\text { Groundwater/ } \\
\text { River-Lake }\end{array}$ & $\begin{array}{l}\text { Waste Water } \\
\text { Treatment/Reuse }\end{array}$ & Seawater \\
\hline E/WR (KWh/m3 & $0.1-0.5$ & $1-2.5$ & $2.5-8.5$ \\
\hline
\end{tabular}


Table 5. Relationship between land, water footprint, chemicals footprint and carbon footprint of the tomato production (Chico et als 2010; Chapagain and Orr 2009; Torrellas et als 2012)

\begin{tabular}{|c|c|c|c|c|c|c|c|c|}
\hline \multicolumn{2}{|c|}{ Production System } & \multicolumn{2}{|c|}{$\begin{array}{l}\text { Green } \\
\text { Water } \\
\text { Footprint } \\
\text { (m3/ton) } \\
\end{array}$} & $\begin{array}{l}\text { Blue } \\
\text { Water } \\
\text { Footprint } \\
\text { (m3/ton) }\end{array}$ & $\begin{array}{l}\text { Grey } \\
\text { Water } \\
\text { Footprint } \\
\text { (m3/ton) }\end{array}$ & $\begin{array}{l}\text { Productivity } \\
(\mathrm{Kg} / \mathrm{m} 2 \\
\text { year })\end{array}$ & $\begin{array}{l}\text { Chemical } \\
\text { Energy } \\
\text { (Kcal/m2 } \\
\text { year) }\end{array}$ & $\begin{array}{l}\text { Water } \\
\text { (m3/ton) }\end{array}$ \\
\hline \multicolumn{2}{|l|}{ Rainfed } & \multicolumn{2}{|c|}{158} & ........... & 808 & $1-4$ & $0.18-7.2$ & 966 \\
\hline \multicolumn{2}{|l|}{ Irrigated } & \multicolumn{2}{|c|}{7} & 110 & 149 & $4-8$ & $7.2-14.6$ & 266 \\
\hline \multicolumn{2}{|l|}{ Greenhouse } & \multicolumn{2}{|c|}{-------------- } & 66 & 121 & $10-12$ & $54-72$ & 179 \\
\hline \multicolumn{2}{|l|}{ Greenhouse } & \multicolumn{2}{|c|}{$\mathrm{N}$} & $\mathrm{P}$ & $\mathrm{K} 2 \mathrm{O}$ & Insecticides & Fungicides & \\
\hline \multicolumn{2}{|l|}{$\mathrm{Kg} / \mathrm{ha}$} & \multicolumn{2}{|c|}{800} & 500 & 1500 & 3,8 & 28,5 & \\
\hline $\begin{array}{l}\text { Carbon } \\
\text { Footprint }\end{array}$ & \multicolumn{2}{|c|}{ Structure } & Climat. & $\begin{array}{l}\text { Auxiliary } \\
\text { equipment }\end{array}$ & Fertilizers & Pesticides & Waste & $\begin{array}{l}\text { TOTAL } \\
\text { Greenhouse }\end{array}$ \\
\hline $\begin{array}{l}\mathrm{kgCO} 2 / \mathrm{ton} \\
\text { tomato }\end{array}$ & 88 & & 15 & 77 & 82 & 2 & 3.1 & 250 \\
\hline
\end{tabular}


Table 6. Risks in the Energy-Water-Food System from a supply chain view.

\begin{tabular}{|c|c|c|c|}
\hline RISKS & $\begin{array}{l}\text { NATURAL } \\
\text { CAPITAL }\end{array}$ & $\begin{array}{l}\text { ECONOMIC } \\
\text { CAPITAL }\end{array}$ & $\begin{array}{l}\text { SOCIAL } \\
\text { CAPITAL }\end{array}$ \\
\hline AVAILABILITY & $\begin{array}{l}\text { Supply of ecosystem } \\
\text { services. } \quad \text { Variability } \\
\text { and degradation. }\end{array}$ & $\begin{array}{lr}\text { Unsustainable resources } \\
\text { exploitation. } & \text { Local } \\
\text { depletion of resources }\end{array}$ & Governance and Conflicts \\
\hline ACCESS & $\begin{array}{l}\text { Climate Change. } \\
\text { Extreme Events. Local } \\
\text { Depletion }\end{array}$ & $\begin{array}{lcr}\text { Planning, design and } & \text { and } \\
\text { economic support } & \text { of } \\
\text { Infrastructures } & \end{array}$ & $\begin{array}{l}\text { Energy poverty, clean water } \\
\text { and sanitation and } \\
\text { undernutrition and obesity }\end{array}$ \\
\hline UTILISATION & $\begin{array}{l}\text { Local Ecosystems } \\
\text { irreversible damaged }\end{array}$ & $\begin{array}{l}\text { Supply Chain Added } \\
\text { Value. Global Trade. }\end{array}$ & $\begin{array}{l}\text { Global agreements. Equity } \\
\text { and efficiency }\end{array}$ \\
\hline
\end{tabular}

